\title{
Establishing a Pilot Interprofessional Education Program in a Higher Education Institution in the Philippines
}

\author{
https://doi.org/10.37719/jhcs.2020.v2i2.rna004
}

MICHAEL P. SY, PhD1

https://orcid.org/0000-0003-0849-2874

REEVA ANN L. SUMULONG, MS 3,4

https://orcid.org/0000-0001-8745-1274
ROI CHARLES S. PINEDA, MSc 2

https://orcid.org/0000-0002-8224-8725

ANNALYN T. NAVARRO, DrPH ${ }^{5}$

https://orcid.org/0000-0002-5425-8811

1National Teacher Training Center for the Health Professions, University of the Philippines Manila

2Department of Rehabilitation Sciences, Katholieke Universiteit Leuven

${ }^{3}$ Center for Inter-Professional Education and Practice, De La Salle Medical and Health Sciences Institute

${ }^{4}$ College of Pharmacy, De La Salle Medical, and Health Sciences Institute

${ }^{5}$ College of Allied Medical Professions, Angeles University Foundation

\section{Corresponding author's email: navarro.annalyn@auf.edu.ph}

\section{Abstract}

A pilot interprofessional education (IPE) program in the Philippines has been initiated in a private higher education institution by three Filipinos who were formally trained in IPE from a World Health Organization (WHO) Collaborating Centre for Research and Training on IPE. Guided by the WHO educator and curricular mechanisms on IPE and an understanding of the local context, a fourstep action plan was created for the pilot IPE program, which involved 10 health science programs. The experience from the initial implementation was challenging and required perseverance as well as inclusive leadership. Nevertheless, the program's accomplishments such as continuous faculty training in IPE, constant communication among faculty members and students on IPE, and an interuniversity collaboration to host the first-ever local IPE conference were noted. The article concludes with lessons learned from the pilot IPE program and future directions in further contributing to the growth and sustainability of IPE programs in the Philippines.

Keywords: health professions education, collaborative practice, evaluation, educator mechanism, curricular mechanism 


\section{Introduction}

$\mathrm{T}$ he World Health Organization (WHO) created a global Framework for Action on Interprofessional Education (IPE) and Collaborative Practice (CP) to help steer fragmented health systems into more collaborative ones (WHO, 2010). Its primary objective is to optimize health outcomes for patients and communities. Instrumental in achieving this objective, the WHO framework emphasized the role of higher education institutions (HEI) in developing learning programs that produce CP-ready healthcare workers who are competent in tackling current and future health needs.

Because every educational and health system is different, it can be a challenge to translate this framework into programs that are suited to address local needs and challenges. A group of faculty members from the Angeles University Foundation (AUF), certified IPE trainers from the WHO Collaborative Centre (WHO-CC) for Research and Training on IPE (Gunma University, Japan), took on this challenge. In this short report, we describe our four-step action plan in developing a pilot IPE program in AUF through the trainers' experiences in activating the strategies that shape how IPE is developed and delivered (i.e., educator and curricular mechanisms; WHO, 2010), to produce practice-ready health professionals.

\section{Background}

One of the thrusts of IPE is the alleviation of global healthcare workforce shortage (WHO, 2010) and its implementation in the Philippine education system may be beneficial in addressing the current shortage of Filipino healthcare professionals. Despite this potential, IPE in the Philippines remains a novel approach to healthcare education practice (Paterno \& Opina-Tan, 2014).

AUF, a private university in Central Luzon (located about $80 \mathrm{~km}$ north of the Philippine capital of Manila), is one of the few universities in the region offering a wide range of degree programs in health sciences including medicine, nursing, pharmacy, medical technology, radiologic technology, physical therapy, and occupational therapy. Unfortunately, there was no IPE program being implemented within the university. Thus, faculty members who were certified IPE trainers took the initiative to develop an IPE course that can be integrated into all health science curricula of the university.

Although pushing for curricular changes within multiple degree programs to include IPE can be challenging, this initiative takes advantage of the current nationwide educational reform happening in the country. The reform mandates the transition of pre-tertiary education from a 10-year to a 12year curriculum resulting in no new enrollees for academic years 2016-2017 and 2017-2018, as well as the call to promote transformative learning and 21st-century skills in higher education (WHO, 
2013). HEls, including AUF, are revising their curricular offerings to align them to the profiles of prospective university students. This allows the integration of IPE into each of the revised curricula rather than a mere addition to existing ones.

\section{Approach}

Three IPE trainers, faculty members from the university, worked together as the steering committee to establish a program called "Pilot IPE Program" in AUF. In late 2015, an initial meeting was held to outline the process of creating the program, distribute tasks to the team members, and identify possible obstacles throughout the process. Guided by the WHO's framework, particularly on the educator and curricular mechanisms and levels of engagement, a four-step action plan was created that spanned for three years.

\section{Action Plan 1: Program Development}

The IPE trainers scheduled several meetings in eight months (between 2015 and 2016) to discuss the contents of the IPE program. Initially, knowledge, skill, and attitude competencies were identified, followed by determining relevant topics, teaching-learning strategies, and assessment measures that will facilitate learning outcomes. The outputs of the meetings were synthesized in a Learning Activity Sheet (LAS).

\section{Action Plan 2: Negotiation with University Administrators}

While the initiative was from the "grassroots", a top-down implementation approach to spread IPE and CP within the university was preferred (Bishop, 2016). One of the problems foreseen was that other departments, aside from the home departments of the IPE trainers, would lack enthusiasm for or even reject this IPE initiative. Before this IPE initiative, different units had little to no interprofessional work between them and had reservations regarding sharing their authority over their department with members of other units. Part of the proposed solution was to seek the support of the university's administrators. It was easier to break barriers between departments and ask for human and material resources needed when the top management was tapped first. Nonetheless, constant conversations on IPE and CP with faculty members and students were equally necessary.

\section{Action Plan 3: Implementation of a Pilot IPE Program}

The pilot program was a four-hour activity that engaged 10 professions which began with two 20-minute lectures covering: (1) basic principles in IPE and CP and (2) IPE and CP process as applied in the local context. A short orientation on the workshop tasks was provided following the lectures. Thereafter, the cohort was divided into smaller groups to better facilitate discussion of a specific case vignette (i.e., medical, community health, and domestic violence/social issue). Guide questions were explicitly outlined in the LAS to structure their discussion (see Supplemental Material). 
The IPE trainers facilitated team competencies such as (1) telling one's role to the team, (2) explaining observations and assessment, (3) agreeing on a collective plan for the team, and (4) moving as a team to accomplish the task of presenting outputs to the class. Steps one and two were done by presenting their uniprofessional roles, observations, and assessments in an interprofessional group. For steps three and four, participants were expected to agree or disagree as a team and consolidate their interprofessional care plans through a five-minute oral presentation. Finally, the IPE program concluded by asking volunteers to share their IPE experience with the whole class. Feedback was given both by trainers and participants. The experiences shared were transcribed for documentation. Likewise, photos and videos during these IPE activities were disseminated inside the university and in social media outlets.

\section{Action Plan 4: Program Evaluation}

Like any program, the pilot IPE program was designed and constructed including a program evaluation using the Context-Input-Process-Product (CIPP) Model (Stufflebeam \& Shinkfield, 2007) three years after its implementation to determine the extent of the program's impact, strengths, weaknesses, and areas for improvement. Also, the results can be the basis for the future directions of the IPE program in AUF.

\section{Findings}

Our action plan involved identified key players who propelled the pilot IPE program and each plan was characterized by a specific level of engagement: contextualize, commit, and champion (see Table 1). Contextualize means agreeing to implement IPE-CP that would involve and benefit the local community. Commit refers to sustaining IPE programs through evidence generation (research and evaluation) and policymaking. Champion pertains to actively encouraging leaders in various institutions and management teams to share a commitment towards IPE and support its principles through policies, practice, and scholarship. Moreover, each strategy within the educator and curricular mechanisms based on the WHO framework (WHO, 2010) were explored by synthesizing the trainers' experiences (see Table 2). We would like to outline our findings by discussing the facilitators and barriers framed by the IPE educator and curricular mechanisms.

Introducing IPE through the implementation of a pilot IPE program in a private university required much time, physical and mental effort, effective communication, and commitment. Identified facilitators and barriers towards the success of this pilot IPE program were noted to be used later for program evaluation and revision. Moreover, to put a structure in evaluating the impact of the pilot IPE program, the strategies from educator and curricular mechanisms were juxtaposed with the experiences of the IPE trainers from the implementation of the pilot IPE program. 
Educator Mechanism. Trained educators who are well-versed in facilitating IPE-CP competencies are crucial to the success of IPE within higher education institutions. They are expected to initiate a steering committee within the university that will lead in the training, program development, curriculum revision, manual creation, and championing of IPE to university officials, teaching staff, and surrounding communities.

Table 1. Summary of the four-step action plan including the timeline, key players, and level of engagement

\begin{tabular}{|c|c|c|c|}
\hline Action Plan & Timeline & Key players & Level of engagement \\
\hline $\begin{array}{l}\text { Step } 1 \\
\text { Program } \\
\text { development }\end{array}$ & $\begin{array}{c}\text { November } 2015 \text { to } \\
\text { July } 2016\end{array}$ & IPE-CP trainers & $\begin{array}{l}\text { Contextualize: The trainers have } \\
\text { trained abroad and, during program } \\
\text { development, they made sure to } \\
\text { tailor-fit their learning into the local } \\
\text { context. }\end{array}$ \\
\hline $\begin{array}{l}\text { Step } 2 \\
\text { Negotiation with } \\
\text { university } \\
\text { administrators }\end{array}$ & $\begin{array}{l}\text { July } 2016 \text { to } \\
\text { August } 2016\end{array}$ & $\begin{array}{l}\text { IPE-CP trainers, } \\
\text { university officials } \\
\text { (college deans, } \\
\text { university } \\
\text { president), HRDC }\end{array}$ & $\begin{array}{l}\text { Commit: The university officials } \\
\text { approved the program, which was } \\
\text { consequently promoted by the } \\
\text { HRDC. College deans encouraged } \\
\text { their faculty members and students } \\
\text { to participate in the pursuit of faculty } \\
\text { development and extracurricular } \\
\text { learning, respectively. }\end{array}$ \\
\hline $\begin{array}{l}\text { Step } 3 \\
\text { Implementation of } \\
\text { the pilot IPE } \\
\text { program }\end{array}$ & $\begin{array}{l}\text { September } 2016 \\
\text { to December } 2016\end{array}$ & $\begin{array}{l}\text { IPE-CP trainers, } \\
\text { HRDC, faculty } \\
\text { members, students, } \\
\text { and non-teaching } \\
\text { staff }\end{array}$ & $\begin{array}{l}\text { Commit: The IPE trainers ensured } \\
\text { that the pilot IPE program was } \\
\text { framed within outcomes-based } \\
\text { education and adult learning } \\
\text { principles. The program was } \\
\text { conducted on three distinct cohorts } \\
\text { within the university. }\end{array}$ \\
\hline $\begin{array}{l}\text { Step } 4 \\
\text { Program evaluation }\end{array}$ & July 2018 & $\begin{array}{l}\text { IPE-CP trainers, } \\
\text { college dean, and } \\
\text { participants of the } \\
\text { pilot IPE program }\end{array}$ & $\begin{array}{l}\text { Champion: The results of the } \\
\text { program evaluation aims to guide } \\
\text { the team in developing the IPE } \\
\text { program and also identify an IPE } \\
\text { champion per department who will } \\
\text { sustain the cycle of IPE } \\
\text { opportunities in AUF. }\end{array}$ \\
\hline
\end{tabular}

IPE, interprofessional education; CP, collaborative practice; HRDC, Human Resource, and Development Center

Curricular Mechanism. Being able to teach IPE is not enough because before implementing an instructional design, a well-planned curriculum must be installed first. It was advantageous that two of the IPE trainers were formally trained in educational sciences particularly on curriculum development. This factor is crucial in the development of the pilot IPE program. Table 2 summarizes how the IPE trainers strategized to ensure that learning activities, expected outcomes, and assessment of learning are interlinked to achieve effective IPE in AUF.

In terms of educator mechanisms, barriers arose from managerial commitment. Even though constant dialogue with the administration, teaching staff, and non-teaching workers in the university 
existed, their initial engagement might be inconsistent or even absent due to priorities, values, and openness to new ideas. However, with the presence of institutional support as well as champions who were formally trained in IPE and educational sciences, the commitment of faculty and staff to join the pilot program was further facilitated, evidenced by the successful IPE program implementation to over a hundred participants.

On the other hand, barriers to curricular mechanism could be from logistics and scheduling. The date was moved three times because of calendar changes. The bureaucracy of communication with colleges, departments, and units was one of the most challenging aspects of the project. There was a particular college that was particularly unenthusiastic about the idea and the trainers would have to utilize strategies that would showcase the benefits of the program to their faculty members and students. Another hurdle was the short amount of time given for the program. Ideally, an IPE program would have more than one session stretched within a week or a month. During the next program implementation, the IPE trainers also intend to resolve the following: making attendance compulsory and involving a graded

Table 2. Experiences of trainers in applying the educator and curricular mechanisms for the pilot interprofessional education (IPE) program

\begin{tabular}{|c|c|c|c|}
\hline $\begin{array}{c}\text { Educator } \\
\text { Mechanisms }\end{array}$ & AUF Experience & $\begin{array}{c}\text { Curricular } \\
\text { Mechanisms }\end{array}$ & AUF Experience \\
\hline Champions & $\begin{array}{l}\text { The IPE trainers } \\
\text { championed IPE in AUF and } \\
\text { shouldered the necessary } \\
\text { work to move the IPE } \\
\text { initiative from plans to a } \\
\text { working pilot program. }\end{array}$ & $\begin{array}{l}\text { Logistics \& } \\
\text { scheduling }\end{array}$ & $\begin{array}{l}\text { The IPE "champions" of AUF } \\
\text { managed the logistics of the IPE } \\
\text { initiative and were flexible in } \\
\text { accommodating scheduling } \\
\text { differences between different } \\
\text { departments }\end{array}$ \\
\hline $\begin{array}{l}\text { Institutional } \\
\text { support }\end{array}$ & $\begin{array}{l}\text { Support from the university } \\
\text { administration was sought at } \\
\text { the beginning and this made } \\
\text { the whole process easier. } \\
\text { Before this, the IPE trainers } \\
\text { faced a lack of cooperation } \\
\text { from other departments. }\end{array}$ & $\begin{array}{l}\text { Program content } \\
\text { \& learning } \\
\text { methods }\end{array}$ & $\begin{array}{l}\text { Because AUF has no IPE courses, } \\
\text { the pilot program always began with } \\
\text { an introduction of IPE concepts. A } \\
\text { case discussion follows the lecture } \\
\text { and it ends with a short } \\
\text { presentation from each group about } \\
\text { their learning. }\end{array}$ \\
\hline $\begin{array}{l}\text { Managerial } \\
\text { commitment }\end{array}$ & $\begin{array}{l}\text { With a shared vision, the } \\
\text { IPE trainers constantly } \\
\text { engaged the faculty } \\
\text { members and non-teaching } \\
\text { staff in formal and informal } \\
\text { dialogues. Different units } \\
\text { were invited to participate, } \\
\text { support, and contribute to } \\
\text { the IPE initiative. }\end{array}$ & $\begin{array}{c}\text { Shared } \\
\text { objectives }\end{array}$ & $\begin{array}{l}\text { Despite each group being } \\
\text { composed of persons with a } \\
\text { different professional background, } \\
\text { the learning objectives were crafted } \\
\text { for them to accomplish one goal. } \\
\text { The lecture on the IPE concepts } \\
\text { also provided everyone with the } \\
\text { same background knowledge on } \\
\text { IPE. }\end{array}$ \\
\hline $\begin{array}{l}\text { Learning } \\
\text { outcomes }\end{array}$ & $\begin{array}{l}\text { Learning outcomes were } \\
\text { adapted based on learners' } \\
\text { profiles in each cohort } \\
\text { (undergraduate students, }\end{array}$ & $\begin{array}{l}\text { Contextual } \\
\text { learning }\end{array}$ & $\begin{array}{l}\text { Case studies were based on health } \\
\text { and social issues relevant to } \\
\text { Filipinos (e.g., poverty, domestic } \\
\text { violence, environmental pollution, }\end{array}$ \\
\hline
\end{tabular}




\begin{tabular}{|c|c|c|c|}
\hline $\begin{array}{c}\text { Educator } \\
\text { Mechanisms }\end{array}$ & AUF Experience & $\begin{array}{c}\text { Curricular } \\
\text { Mechanisms }\end{array}$ & AUF Experience \\
\hline & $\begin{array}{l}\text { graduate students, and } \\
\text { faculty members). }\end{array}$ & & and lack of healthcare access). \\
\hline Staff training & $\begin{array}{l}\text { The program is considered } \\
\text { the first staff training on IPE. } \\
\text { Thereafter, the faculty } \\
\text { members who attended the } \\
\text { pilot program would adapt it } \\
\text { to suit the needs of their } \\
\text { respective departments with } \\
\text { the assistance of the IPE } \\
\text { trainers. }\end{array}$ & Assessment & $\begin{array}{l}\text { The pilot IPE program utilized the } \\
\text { Attitudes Towards Health Care } \\
\text { Teams Scale (Heinemann et al., } \\
\text { 2002) for the assessment of team } \\
\text { attitudes towards IPE-CP and the } \\
\text { institutional teacher's evaluation. } \\
\text { Moreover, a formal program } \\
\text { evaluation is scheduled to gain } \\
\text { further insights regarding curriculum } \\
\text { (re)design. }\end{array}$ \\
\hline
\end{tabular}

AUF, Angeles University Foundation; CP, collaborative practice

assessment. With many aspects to improve on, the program content already consisted of achievable learning outcomes and used various learning methods grounded on adult learning principles. Ultimately, the accomplishments and points for improvement from the experience must point back to the goals of IPE-CP, which are to produce graduates who are CP-ready and develop faculty members to be outcomes-focused and transformative educators. One educator participant even mentioned, "Knowing other professions' roles within the team helped me understand and perform my role better", a comment that attested to how these two goals were achieved from the pilot IPE experience.

Lastly, program evaluation using the CIPP model was employed. It was carried out through a focused group discussion and results were categorized based on the four aspects of the model as outlined in Table 3. The results of the program evaluation reflected aspects of the pilot IPE program that need to be addressed including facilities, sustainability, departmental initiatives, research, and staff training. Utilizing the CIPP model ensured that the four areas of the pilot IPE program-namely context (overall goals and missions), input (plans and resources), process (activities or components), and product (outcomes or objectives)-were assessed. Consequently, the results of the program evaluation provided evidence-informed decisions to upscale the existing IPE program in AUF.

Table 3. CIPP evaluation of the interprofessional education (IPE) pilot program in the Angeles University Foundation (academic years 2015-2018)

\begin{tabular}{lll}
\hline CIPP Aspect & \multicolumn{1}{c}{ Purpose } & \multicolumn{1}{c}{ Findings } \\
\hline & $\begin{array}{l}\text { Establish the needs } \\
\text { which the program aim } \\
\text { to fill and identify the }\end{array}$ & $\begin{array}{l}\text { - Needs: lack of collaboration in actual practice, open- } \\
\text { mindedness, awareness of other health professions }\end{array}$ \\
& social, political, and & Opportunities: IPE can enhance collaborative practice and \\
there is no IPE program established yet
\end{tabular}




\begin{tabular}{|c|c|c|}
\hline CIPP Aspect & Purpose & Findings \\
\hline \multicolumn{3}{|r|}{ in the Philippines } \\
\hline Input & $\begin{array}{l}\text { Identify material, } \\
\text { time, resources } \\
\text { needed for the IPE } \\
\text { program }\end{array}$ & $\begin{array}{l}\text { - Case vignettes that are timely and contextualized } \\
\text { - Variety of methods to facilitate IPE training aside from the } \\
\text { KJ method* } \\
\text { - Inclusion of aspects of spiritual health } \\
\text { - Specific point persons and appropriate continuing faculty } \\
\text { development programs to train facilitators }\end{array}$ \\
\hline Process & $\begin{array}{l}\text { Monitor whether } \\
\text { program activities are } \\
\text { carried out as } \\
\text { planned }\end{array}$ & $\begin{array}{l}\text { - Implemented in some classes but barriers are also evident } \\
\text { - The idea is something that is not new in the field but is not } \\
\text { referred to as IPE and collaborative practice } \\
\text { - Should be implemented after their training in their } \\
\text { respective classes } \\
\text { - Not fully implemented due to facilities and scheduling of } \\
\text { classes }\end{array}$ \\
\hline Product & $\begin{array}{l}\text { Assess the outcome } \\
\text { of the program }\end{array}$ & $\begin{array}{l}\text { - More positive attitudes towards IPE } \\
\text { - Increased interest in venturing into IPE-related researches } \\
\text { - No established network yet to further promote IPE and } \\
\text { collaborative practice } \\
\text { - A limited number of IPE-related researches } \\
\text { - No integration of IPE yet in the curriculum } \\
\end{array}$ \\
\hline
\end{tabular}

*The Kawakita Jiro Method or "KJ Method" is a Japanese problem-solving approach utilizing divergent and convergent thinking, idea crystallization, and idea-verification (Kunifuji, 2016). This method is characterized as a post-lecture workshop where participants are divided into small groups to discuss a question or a topic. Each participant in a group is allowed to discuss or answer a question by writing their ideas on paper cards, which will then be arranged according to themes on a board or manila paper. The participants may then decide to add arrows, color coding, and drawings to visualize and to convey meanings and associations among the ideas. The end product is an idea board that can be used for oral presentation later post-workshop

\section{Lessons and Future Directions}

Based on the action plan described above, we would like to highlight accomplishments, identify present barriers, and articulate future directions of this pilot IPE program. The consideration of the educator and curricular mechanisms described in the action framework (WHO, 2010) guided the trainers to devise context-focused actions in implementing IPE and CP in AUF. Trained educators who are well-versed in facilitating IPE and CP competencies were crucial to the successful implementation of the pilot IPE program. Barriers remained to be the managerial commitment to install a novel approach such as IPE due to different institutional priorities. Nonetheless, two new faculty members who were recently trained in IPE under the WHO-CC were assigned to form the IPE committee that would lead in integrating IPE and CP competencies within certain courses in different curricula enabling greater fluidity among faculty members across departments. To sustain this, an IPE champion would be assigned per department and the IPE program is expected to be done in another cycle to activate the integration of IPE within health science curricula in the next three years. While the four-step action plan provided structure in the development of the pilot IPE program, a more rigorous development process may be followed such as the "Interprofessional Education Guidelines 2017" released by the Center for the Advancement of Interprofessional Education (Barr, et al. 2017) 
to ensure improvement and sustainability of IPE within AUF.

Alternatively, the heightened awareness of IPE and CP among the faculty members and students also ignited AUF to collaborate with another private university to host the first-ever "Philippine Interprofessional Education and Collaboration Conference" held last 11-12 August 2018 in Manila, Philippines. The post-conference workshop instigated the establishment of the informal and online group for Filipino IPE champions called the "Philippines Interprofessional Education and Collaboration Network" (PHIPEC Network) (Sy et al., 2019). To uphold all the level of engagementscontextualize, commit, and champion-AUF collaborated with the PHIPEC Network and two other private universities to host the 2nd Asia Pacific Interprofessional Education and Collaboration and PHIPEC Network Joint International Conference entitled "Transforming Asian Healthcare and Social Welfare through Interprofessional Education and Collaboration in the $21^{\text {st }}$ Century" (see https://www.phipecnet.org). Additionally, AUF has since continued demonstrating commitment towards IPE and CP through community extension projects that emphasize upskilling CP competencies among health care profession faculty members and students as well as evidence generation of Filipino students' readiness towards IPE (Cervantes-Sudio et al., 2020).

Navigating the bureaucracy and governance within higher education could be overwhelming especially when novel ideas and approaches are being introduced. The experience of AUF is a testament that establishing an IPE program is challenging and requires perseverance. However, inclusive leadership and being constantly mindful of different levels of leadership engagement made the whole experience worthwhile.

Hence, the following key lessons were learned throughout the experience:

- Early planning. Planning early and setting a timeline is crucial to involve more professions, secure adequate resources, minimize logistical difficulties, and allow ample time to negotiate with university officials. Moreover, it is strategic to establish rapport with the university units involved through the process of implementing the action plans. Likewise, a plan to evaluate the program must be set and scheduled to monitor the (non)achievement of targeted outcomes and to inform the college and university on the decisions to be made for IPE.

- Professional identity. Having a professional identity is advisable when joining the IPE program. Having this competency enables participants to share based on their professional background producing valid assumptions for their colleagues during discussions resulting in richer interprofessional learning and exchange.

- Congruence between learning and adult learner. In designing an IPE program, it is crucial to tailor-fit the learning outcomes, teaching-learning strategies, and assessment methods to the learners' profile. The case vignettes should be crafted to reflect health and social issues that are relevant and timely to activate the sharing of opinions, insights, and personal experiences.

- Documentation. The habit of documenting via written works, photos, videos, or social media makes the IPE program establishment more official, evidence-generating, and organized. The 
raw data collected throughout the documentation process eases the process of information dissemination via presentation, publication, or grant application.

We hope that this Research Note provides health and caring sciences educators, scholars, and program developers a guide to design and redesign innovative programs introduced within higher education institutions. While the four-step action plan is not prescriptive, this article intends to propose that each program must be grounded on theoretical frameworks, contextualized based on the needs of the end-users and stakeholders, and sustained through committed scholarship and deliberate translation of research to actual products that will benefit both the education and health systems.

\section{Conflict of Interest}

The authors have no conflict of interest to disclose.

\section{Acknowledgement}

We are grateful for the openness and support given to us by Dr. Joseph E. L. Angeles (AUF President), Dr. Archimedes T. David (Vice President for Academic Affairs), and the Human Resource and Development Office to introduce interprofessional education and practice within the university. We also appreciate the faculty members, graduate students, and undergraduates students for their willingness to participate in this innovative strategy.

\section{Funding}

The authors have no funding to disclose.

\section{Author Contribution}

Michael P. Sy: study conceptualization, program development, and evaluation, project administration and supervision, writing-original draft preparation, writing-review, and editing. Roi Charles S. Pineda: study conceptualization, program development, and evaluation, writing-original draft preparation, writing-review, and editing. Reeva Ann L. Sumulong: study conceptualization, program development, and evaluation, writing-review, and editing. Annalyn T. Navarro: study conceptualization, project administration, and supervision. 


\section{Disclaimer}

The first three authors were formerly affiliated with the Angeles University Foundation at the start of the implementation of the pilot IPE program (the academic year 2015-2016).

\section{References}

Barr, H., Ford, J., Gray, R., Helme, M., Hutchings, M., Low, H., Machin, A., \& Reeves, S. (2017). Interprofessional education guidelines 2017. Center for the Advancement of Interprofessional Education. https:/www.caipe.org/resources/publications/caipe-publications/caipe-2017-interprofess ional-education-guidelines-barr-h-ford-j-gray-r-helme-m-hutchings-m-low-h-machin-reeves-s

Bishop, W. (2016). Integrating IPE into an academic health sciences center: A bottom-up and top-down approach. International Journal of Health Sciences Education, 3(2), 1-7. https://dc.etsu.edu/ijhse/vol3/iss2/2

Cervantes-Sudio, M. G., Ganotice, F. A., \& Navarro, A. T. (2020). Are Filipino students ready to collaborate? Comparing the readiness of healthcare students for interprofessional education in the Philippines. Journal of Interprofessional Care. Advance online publication. https://doi.org/10.1080/13561820.2020.1806215

Heinemann, G. D., Schmitt, M. H., \& Farrell, M. P. (2002). Attitudes toward health care teams. In G. D. Heinemann \& A. M. Zeiss (Eds.), Team performance in health care: Assessment and development (pp. 155-159). Kluwer Academic/Plenum.

Kunifuji S. (2016). A Japanese problem-solving Approach: The KJ Ho Method. In A. Skulimowski \& J. Kacprzyk (Eds.), Knowledge, information and creativity support systems: Recent trends, advances, and solutions. Advances in intelligent systems and computing, 364. Springer, Cham. https://doi.org/10.1007/978-3-319-19090-7_13

Paterno E. \& Opina-Tan L. A. (2014). Developing community-engaged interprofessional education in the Philippines. In D. Forman, M. Jones, \& J. Thistlethwaite (Eds.), Leadership development for interprofessional education and collaborative practice (pp. 162-178). Palgrave Macmillan.

Stufflebeam, D. J., \& Shinkfield, A. J. (2007). Evaluation theory, models, and applications. Jossey-Bass.

Sy, M. P., Escuadra, C. J., \& Sumulong, R. A. L. (2019). The birth of a national network for interprofessional education and collaboration: Results from an inter-university partnership. Philippine Journal of Allied Health Sciences, 3(1). https://doi.org/10.36413/pjahs.0301.007

World Health Organization. (2010). Framework for action on interprofessional education and collaborative practice. The Organization.

World Health Organization. (2013). Transforming and scaling up health professionals' education and training: World Health Organization guidelines 2013. The Organization. https://www.who.int/hrh/resources/ transf_scaling_hpet/en/ 
Michael P. Sy, PhD, MHPEd, OTRP, is an associate professor at the National Teacher Training Centre for the Health Professions (NTTCHP), University of the Philippines Manila. He is an occupational therapist by profession. Apart from his research and works in occupational therapy, occupational science, justice health, and health professions education, he is also actively championing interprofessional education and practice in his country through the Philippine Interprofessional Education and Collaboration Network (PHIPEC Network). In NTTCHP, Dr. Sy will be leading the graduate-level courses on interprofessional education starting academic year 2020-2021. Dr. Sy is also an active member of the Centre for the Advancement of Interprofessional Education (CAIPE) research group and volunteers as a short report editor for the Journal of Interprofessional Care.

Roi Charles S. Pineda, MSc, is an occupational therapist and adapted physical activity specialist with experience as clinical practitioner, researcher and educator. His early practice was in acute and subacute physical rehabilitation. He has since diversified his professional interest to include health promotion among individuals with disabilities using physical activity from the continuum of recreation to high-performance sport. He is currently completing his doctoral studies in biomedical sciences at KU Leuven (Belgium). His research is on the effect of sport expertise and intellectual impairment on multi-tasking. He also works with the International Paralympic Committee as a certified classifier for athletes with intellectual impairment.

Reeva Ann L. Sumulong, MS, is an associate professor at the College of Pharmacy and the Director of the Center for Inter-Professional Education and Practice at the De La Salle Medical and Health Sciences Institute. She is currently doing her $\mathrm{PhD}$ in Curriculum and Instruction at Philippine Normal University. Both a pharmacist and a teacher by profession with a Master of Science in Chemistry, she is one of the few Filipinos who was formally trained in IPE from Gunma University (Japan). Aside from her interests in interprofessional education, she is also interested in global citizenship education and multicultural education.

Annalyn T. Navarro, DrPH, is an associate professor and Dean of the College of Allied Medical Professions in Angeles University Foundation (AUF). Recently, she was appointed as the Chair of the Health Sciences Program of the Graduate School of AUF. She is a medical technologist by profession and a licensed professional teacher. She completed her Master of Arts in Education major in Educational Management and Doctor of Public Health major in Health Promotion and Education in AUF. With her experience as an educational administrator and academic in the health sciences, Dr. Navarro has been very effective in providing strategic support in innovative programs including IPE that will enhance the education and training of future health professionals. 